\title{
Indigenous Marital Therapy: A Case of Botswana
}

\author{
Bakadzi Moeti ${ }^{1} \&$ Hildah L. Mokgolodi ${ }^{1}$ \\ ${ }^{1}$ Lecturer, Department of Educational Foundations, University of Botswana, Botswana \\ Correspondence: Bakadzi Moeti, Lecturer, Department of Educational Foundations, University of Botswana, Botswana.
}

Received: August 9, 2017

doi:10.11114/ijsss.v5i11.2582
Accepted: September 25, $2017 \quad$ Available online: October 30, 2017

URL: https://doi.org/10.11114/ijsss.v5i11.2582

\begin{abstract}
Botswana has a long history of indigenous marital therapy. This indigenous therapy is embodied in the indigenous philosophy of motho ke motho ka batho (I am because we are). This philosophy promotes togetherness, connectedness, collectiveness, compassion, love and harmony and the building of sustainable relationships among families. The paper explores some of the indigenous therapeutic marital approaches used during wedding ceremonies amongst them, songs, proverbs and group counselling. It also argues that these indigenous marital approaches build family relations and are a continuous source of therapy for the married couple; in addition to relieving women from marital stress and maintaining strong family relationships even after the marriage has ended.
\end{abstract}

Keywords: indigenous marital therapy, approaches, songs, proverbs, group counselling

\section{Introduction}

Marital therapy is a well known concept in many cultures across the world even though every society has their own way of conducting marriage therapy (Nwoye, 2006). This is due to the fact that marriage itself is taken seriously in almost all cultures (Musick \& Bumpass, 2006). This article aims at presenting the indigenous marital approaches used in the society of Botswana. As a result of colonisation there seems to be conflict between western and indigenous marital therapy even though there are similarities and differences between the two. The outcomes of globalisation have resulted in increased nuclearisation (Nwoye, 2006) leading to negligence of old arrangement where therapy was provided by the elders in the families (Stockton, Nitza, \& Bhusumane, 2010). Professional western marital approaches which are heavily influenced by theories and principles of the western family practice (Nwoye, 2006) are slowly misplacing indigenous marital practices (Moeti, Koloi-Keaikitse \&Mokgolodi, 2017). Hence, the authors of this paper had an unfaltering drive to write this paper. The indigenous therapists rely on their experiences and the word of mouth since the processes of marital therapy have not been documented which brings inconsistencies of what is taught during the marital therapy. In addition, the authors are married and have always participated in the marital therapy proceedings. This paper therefore outlines their experiences and attempts to underscore the critical aspects of indigenous therapy that Botswana society seems to be losing in trying to adhere to western therapy. Consequently, the notion of connectedness and relatedness of Setswana culture is slowly fading away. This confirms what Moloko-Phiri, Mulaudzi and Heyns (2016) noted that nowadays, elders apparently prefer to use verses in the Bible during pre-marital counselling instead of indigenous, cultural proverbs.

Botswana is a land-locked country situated in the southern part of the African continent. It has a population of 2 million people which is dominated by females of ages ranging between 15 and above (Population and Housing Census 2011 analytical report). It is one of the most sparsely populated countries in the world. Botswana is made up of two main ethnic groups Tswana people (79\%) and Kalanga people (11\%), then Basarwa (3\%) and other ethnic groups in Botswana (7\%) (Ethnic Groups in Botswana). However, like most of the African countries, these ethnic groups have their own diverse cultures, meaning that there are overlaps, similarities and differences between these cultures. How indigenous marital therapy is conducted varies from culture to culture. There is dearth of literature on indigenous marital therapy in Botswana even though the indigenous marital therapy approaches have always existed and are embedded in the culture of Batswana such as the use of songs, proverbs and idioms as sources of marital therapy.

\section{Background}

Marriage practices vary across the globe. Marriages could be arranged or forced as ukuthwala in the Eastern cape of South Africa (Rice, 2014) or the marriage could be a contractual agreement between consenting partners such as in 
Egypt, Morocco, and Tunisia (Assaad \& Krafft, 2015). Marriage can also be customary or civil as is the case in Botswana (Jobeta \& Nwauche, 2015). This implies that the traditional kind of marriage or marriage sanctioned by courts of law are both legal. However, ontological and epistemological philosophies of a society may determine the outcome of processes and outcomes of marriages in that society. For instance, power based on gender or the economics may decide how and what happens before and during the marriage as Rice (2014) and Assaad and Krafft (2015) point out. Further to the argument on marriage, Solway (2017) is of the view that "Marriage was a "total social phenomenon" entailing the intermingling of the economic, social and political spheres and continual gift circulation, thereby fostering dense social networks' (p.309).

Like in many African nations, marriage in Botswana is recognised as a very important phenomenon. In Namibia, marriage is noted as a way in which families are created (Indongo \& Pazvakawambwa, 2015). It is believed that marriage creates a platform where the societal norms are imparted and learnt. Thus, people were prepared for marriage before they could enter into it. Marital and gender roles seemed to have been imparted in different developmental stages such as at home, in play by children, initiation schools known as bojale (name that refers to initiation schools attended by female children) and boys bogwera (name that refers to initiation schools attended by male children) and marriage itself (Solway, 2016;Amoateng \& Ritchter, 2003; Mogapi, 1994). However, research indicate that many people enter into marriage unprepared as the utmost focus is on the wedding day rather than marriage itself (Foote, 2014). Therefore, marriage preparations are regarded as essential to empower people with skills useful in building stable families (Branch-Harris \& Cox, 2015; Foote, 2005). The indigenous marital therapy is expected throughout a young man or woman's life and specified during the marriage process itself.

In Setswana, marriage is a communal affair. The groom's parents go seek the girls hand in marriage from her parents. As a result of colonialism and embracing some international treaties, Batswana couples can marry without parental consent when they are of age. After parents have met, then a series of activities take place until the marriage day. Sloway (2017) succinctly describes it as a "process of becoming, involving a series of rituals and presentations characterised by a long period of socially productive ambiguity in which the status of the union, the spouses, their children and their broader families remain uncertain" (p309). Marriage signifies connecting the couple, their two families as well as the community at large (Esere, Yeyeodu, \& Oladun, 2014; Ellece, 2010; Mogapi, 1994). By this it means that marriage is displaced from the two who are getting married on to the entire family. This implies that the bride belongs to the groom's family while the groom belongs to the bride's family. This suggests that the whole family is responsible and accountable especially in the provision of a support system for the couple and this is communicated during patlo (asking for hand in marriage) ceremony (Ellece, 2010). It should be noted that as in marriage, the divorce process also involves the extended family structures that married the couple in the first place. Legal systems in Botswana are very much aware of this cultural aspect such that even though the Law allows the couple to process marriage or divorce requests, the systems would always enquire or refer the couple back to the extended family before action is taken. This arrangement promotes healthy relations amongst people and that it may deter and delay those who would want to end their marriage. No wonder in the past marriage was indissoluble! The marriage was destroyed by death and not divorce as it is now (Riessman, 1990). This cultural philosophy promoted communalism rather than individualism which is seen in the western world (Nicolson, 2008). This philosophy is very important because the emphasis is that even after marriage, the couple should have links with the in-laws and extended family members who are always available to offer support. Considering the religious based marital therapy, although it may use western marital therapeutic methods, it rather puts more emphasis on the word of God. For instance, Genesis 2 verse 24 accentuates that the man shall leave his family and cling to his wife (Genesis 2: 24). This verse seem to stress that the couple should be separated from their kinship after marriage something contrary to indigenous marital therapy which promotes communalism. Setswana embodies the philosophy of motho ke motho ka batho (I am because we are), which helps individuals to realize that marriage should not be a burden when one has family and community support. Thus, the rich Setswana culture of relatedness is far felt during Setswana wedding processes such as patlo, bogadi (bride price), go laya (indigenous premarital counselling) and go isiwa ga ngwetsi (escorting the bride to the in-laws place) (Moeti et al., 2017), which are part and parcel of the traditional Setswana marriage process without which the marriage would be regarded invalid (Ellece, 2010).

While the western marriage may end with a honeymoon or at the pronouncing of husband and wife, the Setswana marriage is not over even when legalities are involved. A Setswana marriage continues with taking the bride to her in-laws place (go isiwa ga ngwetsi), after the wedding ceremony which is traditionally performed after the bride price has been paid (Moeti et al., 2017), the bride is escorted by elderly people to her in-laws parents' place where she is further taught about household duties and how to become a good wife. The expectation is that one should learn and interact with her new family. Although this activity brings anxiety, it is a joyous and memorable experience. The process requires both the bride and groom to learn through observation and imitation from the elderly married women 
and men who are projected to be the custodians of knowledge on marriage (Bandura, 1977).

One would realise that indigenous counselling is experiential while western approach is specific and emphasise specialised training. These western or colonial approaches are interested in specifically underlying factors such as in-laws, children, finances, and career related concerns as well as paying attention to referral sources such as the church or friends in premarital counselling (Goldenberg, Stanton \& Goldenberg, 2017). However, it is critical to point out that indigenous approaches are narratives of the experiences of the men and women providing therapy, rather than specific questions asked in western counselling. Indigenous therapy incorporates sociological dimensions that are either ignored or unrecognised by modern therapy (Nwoye, 2000). For instance, central to indigenous therapy are people's experiences and experiential learning, hence the lack of documentation as knowledge is transmitted in shared narratives (Chilisa, Major, Gaotlhobogwe \& Mokgolodi, 2016). Sodi, Esere, Gichinga and Hove (2013) noted that 'in indigenous marital counselling the respect and authority of parents, including the counsel of uncles, aunts and grandparents is of paramount importance' (p, 336). Nwoye (2006) also stressed that aunts and uncles are perceived as indigenous therapists to intervene when need arises. The structure of indigenous therapy allows for continuity of therapy and gives one confidence for one to be married because the couple is allocated an elderly married couple to be their mentor.

As earlier mentioned, in the indigenous marriage the couple belongs to the whole family, such that even when the marriage ends, both parties will be expected to attend family functions, especially, if there are children involved. The woman will still take her role as a mother and the man as the father even if both have remarried. This arrangement can be both therapeutic and disastrous for the new or old spouses. It can root out bitterness from individuals because the person will still be connected to the in-laws family but it can also cause jealousy amongst families, as the couple would still be accorded respect despite the separation or divorce. In addition, the involvement of a divorced spouse is seen as healing when a partner dies. The involvement of the ex-wife in purification activities for instance, is regarded as therapeutic in marriage as it is supposed to give the bereaved a sense of hope as she is still considered a member of the family. As much as extended family relations are seen as therapeutic in African communities this is an exercise which does not seem to be emphasised in western therapies.

Songs and proverbs are useful in relaying therapeutic messages. Botswana has a rich repertoire of songs and proverbs that go together with marriage celebrations. Notably, these different repertoires are used as a source of therapy. It can be concluded that traditional songs speak to the development of people and emphasise teachings conducted privately to make them public knowledge (Moloko-Phiri et al., 2016). Bruscia (1998) noted that songs are often used as they are depicted as to be having distinctive qualities. The nature of song offers unique paths for expression, exploration and experiencing self and others. Songs motivate for an intrinsic quest for meaning and completeness and the creativity of singing allows for opportunities for problem solving. Another scholar, Cottrell (as cited in Aluede \& Iyeh, 2008) stated that "since the beginning of recorded history, music and dance have played significant roles in the healing of human kind. Music, dance and healing were communal activities that were natural to everyone" (p, 15). Although, songs are crucial amongst the Batswana, music as therapy is a less discussed or documented topic.

\section{Therapy through Group Counselling}

As in western approaches, both individual and group therapy are part of indigenous Setswana counselling. However, indigenous approaches emphasise a group system that does not follow set standards of colonial theories but rather experiential theories of Batswana. The group is comprised of married people and the client being the couple or bride or groom who listens to these people's narratives on marriage. Therefore, the process and experience of therapy through indigenous ways and modern ways are completely different based on how learning and transfer of knowledge is perceived. Corey (2011) gives steps to follow when running groups in Western approaches for instance, there is a required number of therapists whereas in indigenous marital therapy the number of therapists is not a concern. The more the therapists the better. Furthermore, the indigenous group processes are not documented (Moeti et al., 2017) while in the western culture they are. It is not surprising that there are variations in indigenous group processes as they are not documented.

Indigenous therapeutic techniques include but are not limited to proverbs and metaphors in language, songs, poems and dance. In the same manner, most of the languages in Africa make use of proverbs to shed light on situations and provide direction about language traditions (Grant \& Asimeng-Boahene, 2006). Chilisa et al., (2016) noted that knowledge transfer is based on the way knowledge itself is made and what makes sense to the people, hence the methodology and techniques used in the therapeutic processes. It is through this that social expectations, new skills, societal values and norms are instilled in people (Masenya, 1998).

As it is believed that setshwarwa ke ntsa pedi ga se thata (teamwork makes work easier), group work is crucial as it promotes collectiveness and relationships among family members. In indigenous marital therapy the parents, extended family members like uncles, aunts and grandparents are of significant status as they have substantial roles they play in 
marriage ( Sodi, Esere, Gichinga, \& Sodi, 2010). These are married men and women who attend and are responsible for providing marital therapy during go laya sessions, a practice of ritual advice that is traditionally performed (Ellece, 2010). Therefore, the bride and the groom are expected to learn, observe and imitate what they are taught (Bandura, 1977) throughout the preparation processes.

\section{Therapy through Songs}

In African setup, societal expectations are instilled in people through songs that convey symbolic meaning and message. The songs may emphasize the notion of botho (aspect of respect) which is a value of Batswana and is embedded in the songs that are sung. Botho strengthens and promotes good families. As the married women continuously sing the songs during wedding celebrations, they are considered to be bringing therapy to those who are getting married and those involved. Some of the songs may bring catharsis while others despair. An example would include songs as Ama woyi woyi zhiyaya oiyelele zhiyaya, Ngwanangu wa yenda ndoko sala nani wee zhiyaya ( $x 2)$ (my daughter is gone, am left alone). This Kalanga song is sung as a source of therapy for the bride's parents especially the mother, who in this case is handing over her daughter for marriage. The bride's mother is on the losing end as she hands over her daughter to the groom's parents. Therefore, the song emphasises that she is left alone. One may interpret the song as suggesting that the daughter is gone for good and will never visit the parents again. Although it is not easy to hand over the daughter, the song is sung to bring a sense of acceptance to the bride's parents that indeed their daughter has joined another family.

Culturally building relationships is of utmost significance. Some songs are sung to build relationships between the bride and groom, between the bride and the mother in-law, as well as between the groom and the in-laws. The expectation is that since the couple will be interacting with several people for the first time they should be ready to embrace them. For example Bana ba no fanilana, ba no fanilana, Ba no fanilana, ee ba no fanilana (These children are a perfect match, yes are a perfect match). Translating this Kalanga song literally, it is a song of acceptance, assuring that the bride and the groom that their decision to get married is a perfect choice. These words cements the love that the two have for each other and also it makes the groom to confidently be rest assured that he has made the best choice. Therefore, the singing part allows new interactions to move smoothly.

Words that emphasise the roles of the bride are embedded in the songs. For instance, Heela mmatsale, mmatsale tlogela dipitsa tseo mong wa tsona mong wa tsone ke yoo o etla, mosutele, mosutele, mosutele, mosutele, ke yoo o etla (hey mother in-law leave those pots because the owner has arrived, give her space give space she is here to take her space). This song is normally sung to welcome the bride to her in-laws place. It emphasizes communalism that the wife is coming to a place where the mother in-law has been in control of the kitchen so the mother-in-law has to create space for the wife to participate in household duties so that together they may know each other better and hence build a relationship. Ellece (2007) has noted that this emphasis is made mainly because the song portray mother-in-laws as people who compete with brides for domestic power. Therefore, the mother in-law is told to create space for the bride and share with her the space that she used to enjoy. Officially she is informed through the song to be ready to acknowledge her daughter's 'in-laws' arrival. Creating space is said to be helping the bride to be involved in the household chores because she has a lot to learn about the family from her mother in-law.

Songs of joy are sung to indicate that the family is no longer going to suffer because a helper has arrived. For example, Mma mosimane itumele, Segametsi se gorogile, itumele (x2) (grooms mother be happy, a helper has arrived, be happy). This song reminds the groom's mother to rejoice because the bride has come to take care of her so this song confirms the bride's roles as a married woman that she has come to assist with household chores. The song portrays her as somebody whose purpose is to collect water using a water calabash. Ellece (2010) finding confirms that the bride's duty is specifically to labour. It is emphasised during the patlo ceremony as the bride is handed to the new family and portrayed as sego sa metsi (a water calabash). Similarly, another song: Re se tsere segonyana sa metsi segonyanasa metsi segonyana sa metsi (x2) (we have taken the water calabash, the water calabash for water). This song is sung to symbolise and remind the bride of her new role or responsibilities as she is getting married. Her duty is to help with household duties such as fetching water using a calabash. (Personal Communication, August 4, 2016). The woman is expected to faithfully serve the in-laws that is why it is believed that the spouse is married to the whole family and not only to his or her spouse.

In another song, Feela feela ngwanyana, feela ngwanyana(x2), o se jele matlakaleng matsale ke seithati, seithati sa mosadi (sweep sweep lady or else you will eat from an untidy place, your mother in-law is a self-loving person sweep sweep or else you will dish from an untidy place); It suggests that the bride should keep her compound and marriage clean and pure. Metaphorically it means the wife should not have extra marital affairs. She is being reminded about womanhood duties of cleaning, that if she doesn't clean she will stay in an untidy place. The groom on the other hand is also expected to take part in the house hold activities such as fetching firewood, slaughtering of animals during family gatherings and cultural activities. 
A bride's beauty can be appreciated through songs for instance, Mosadi yo montle yo, o ne o mmeile kae? Nako tsotlhe o ne o mmeile kae? (x2) (this beautiful wife, where have you been hiding her, all this time where have you been hiding her?). The groom's parents demonstrate their sense of gratitude by questioning the groom where he has been hiding his beautiful woman. On the other hand, the bride is assured that she is beautiful and therefore the in-laws should be glad and celebrate her beauty. The beauty that is emphasized here is both the physical and the inner beauty.

Some songs are sung to permit the groom's parents to send the bride back if she is not executing her duties well or if she is misbehaving. It is sung by the bride's parents to permit the groom's parents that if their child misbehaves they should feel free to bring her back. It is a confirmation and assurance to the groom's family that the bride has been counselled but in the event that she misbehaves they should not fear but feel free to bring her back as there is a way in which married women should portray themselves and behave. For instance,Londolodzani londolodzani

\section{Londolodzani phela}

Ha e lowa mu nzhise

tiwo nlaya kabili (if she is a witch bring her back, we will counsel her again)

However, some of the songs have been interpreted as promoting gender bias, pride and violence amongst people. For instance, the song above emphasis is on the behaviour of the woman and not the man. Struber (2008) found that stereotyping in songs validates gender discrimination and continue structural formations of discrimination against women. Another joyful Kalanga song ; Imi nda wina halala, Ndo wo gala naye, Imi nda lobola nlongo mbuya (I have won oh, I will stay with her, I have married a beautiful woman). Even though this song is sung by the groom's parents especially the mother in-law to portray a sense of joy, the grooms parents victoriously brag that they have taken the bride, hence might be considered as pride. It can be interpreted as if the bride's mother has lost. The groom's parents keep on saying imi nda wina (I have won) as another person has been added to the family. This song is sung to show a sense of gratitude for a new added member to the family. Although the bride's parents would have handed their daughter peacefully and joyfully it might bring pain to the bride's parents when they hear such words. The song also acknowledges the beauty of the bride (Personal Communication, July 16, 2016).

\section{Therapy through Proverbs}

Proverbs enable language users to understand the role of culture, which is indirectly and symbolically, and importantly, reflected in the structure of the specific language (Moloko-Phiri et al., 2016, p246). Although proverbs are used to help the bride know her expectations or new role, the translations of some of the proverbs into English do not adequately reveal their true meaning, for example mosadi tshwene o jewa mabogo (a woman is a baboon, her hands are eaten). It can be confusing to most people who can relate to the proverb in a literal manner. The actual meaning of the proverb is that the bride is expected to work hard in her new role and should ensure that the welfare of the family and the husband is taken care of adequately (Moloko-Phiri et al., 2016).

Proverbs are useful for they assist in passing down tradition and expectations during the group sessions. For instance, a couple might be reminded of the notion that ga gona ntlo e e sa neng (marital problems are unavoidable/ every household has challenges) as such couples are encouraged and prepared psychologically for the challenges ahead. The proverbs packed with African literature are used during go laya (indigenous pre-marital counselling). Even though some proverbs are good, some seem to be relaying a negative message. For example, during the sessions the bride is told never to challenge the husband's promiscuity. However, this is implicated in some of the proverbs which encourage promiscuity especially among men. For instance, the proverb monna ga a botswe gore o tswa kae (never ask about the man's whereabouts) (Ellece, 2011). In cases where this happens, the bride is warned never to challenge her husband's promiscuity. Wives, even during such occurrences, are rather, encouraged to be submissive to their husbands. They are expected to keep respecting, loving and cooking for their husbands as if nothing has happened. As such, this becomes very oppressive as it deprives wives the freedom to inquire about their husband's whereabouts (Togarasei, 2013). One may conclude that it gives men an upper hand to do what they like as they know that they will not be questioned.

The other proverb Monna ke selepe o a fapaanelwa (a man is an axe, he is meant to be shared), encourages men to have more than one sexual lover (Ellece, 2010; Masenya, 2005). This is basically to satisfy men's sexual energy as men are unable to stick to just one sexual partner (Ellece, 2010). Therefore that is why they are culturally permitted to have more than one partner. In trying to support the origin of this viewpoint Togarasai (2013) noted that "possibly originating in the context where axes were few and therefore shared amongst households, the proverb encourages sharing. A man is compared to an axe with the implication that he can be shared by a number of women" (Togarasai, 2013, p.5). With the advent of HIV and AIDS and other sexual transmitted disease, this consequence seem to put women at a health risk. (Ellece, 2010).

Another common word go rutubala (to calm down) is normally used in most cultures especially amongst the 
Bangwaketse (one of the tribes in Botswana) in Kanye and Bakwena (one of the tribes in Botswana) in Molepolole. The bride is simply told that challenges are inevitable in marriage therefore she should learn to deal with those challenges with wisdom and in a calm manner. It also means that the woman should be strong even in the midst of marital storm. She is not advised to leave her home but rather to seek for assistance from the elders from the in-laws side. Divorce in the traditional set-up was very rare; marriage was mostly terminated by death (Riessman, 1990) as compared to these days where divorce is rampant. Go rutubala is demonstrated for the bride to see and learn during go laya. This means that she should not be talkative even when some issues arise but rather maintain a quite mood in some occasions. This is therapy in the sense that the bride is empowered with strategies to use to deal with future marital challenges. This preparation helps the bride to better handle issues with knowledge and understanding as she is made aware of the marital challenges she might find herself in.

The man is considered as the head of the family and this is implied in the proverb monna ke thogo ya lelwapa (a man is the head of the family). Therefore he is the source of support, security and is seen as the provider in terms of food as well as leadership. This proverb gives the groom the responsibility to take care of the wife and children. This finding corroborates the verses in the bible where men are considered the head of the family (Ephesians 5:23 \& 1 Corinthians 11:3). As a result, they are given the respect they deserve although at times they abuse the notion as some do not involve their wives in the decision making process on issues that concern the family. Conflicts and disagreements may arise as a consequence of this.

\section{Conclusion}

Indigenous marital approaches are very important as they are meant to build family relations as well as serve as a continuous source of therapy for the married couple. As in western therapeutic sessions, indigenous therapies also assist in relieving both parties from marital stress and maintain strong family relationships even after the marriage has ended. Therefore, indigenous marital therapy can be seen as developmental, preventive as well as remedial as are modern marital therapy approaches. The indigenous marital approaches are developmental in nature hence provide both therapy and strengthen marriages. Most importantly, the indigenous marital therapy exists to pass down cultural values espoused in the Setswana culture. Using various songs and proverbs during marriage instils societal expectations in the couples. It should be noted that Setswana culture seems to be giving men an advantage over women. Emphasis is more on teaching the woman on how to behave rather than the men. Nowadays, a combination of western and indigenous marital therapy is seen in Botswana. For instance couples may seek for premarital counselling from professional and spiritual counsellors. The only problem is that the indigenous marital practices are gradually fading. It could be good to embrace what is new and incorporate into the culture rather than discarding the old marital therapy practices. Possibly this could reduce the high rates of divorce in the country.

\section{References}

Aluede, C. O., \& Iyeh, M. A. (2008). Music and dance therapy in Nigeria, Voices a World Forum for Music Therapy, $8(1)$.

Assaad, R., \& Krafft, C. (2014). An empirical analysis of the economics of marriage in Egypt, Morocco, and Tunisia. The Oxford Handbook of Africa and Economics.

Bandura, A. (1977). Social learning theory. Englewood Cliffs, NJ: Prentice-Hall.

Branch-Harris, C., \& Cox, A. (2015). The effects of parental divorce on young adult's attitudes towards divorce. Honors Theses, Paper 376.

Bruscia, K. E. (1998). Defining music therapy (2nd ed.). Gilsum, NH: Barcelona.

Ellece, S. (2010). Agency and gender in Setswna marriage ceremonies:'Patlo' and 'go laya' rituals. Journal of Language and Communication, 4(2).

Ellece, S. E. (2007). Gendered Marriage Discourses in Botswana: A CDA Approach. (Unpublished doctoral dissertation). Lancaster University, United Kingdom.

Esere, M. O., Gichinga, E. M., Hove, P., \& Sodi, T. (2010). Marriage and counselling in African. communities: Challenges and counselling approaches. Journal of psychology in Africa, 20(2), 335-340

Esere, M. O., Yeyeodu, A., \& Oladun, C. (2014). Obstacles and suggested solutions to effective communication in marriage as expressed by married adults in Kogi state, Nigeria. Procedia-Social and Behavioral Sciences, 114, 284-592. https://doi.org/10.1016/j.sbspro.2013.12.751

Ethnic groups in Botswana, free encyclopaedia retrieved 15 August 2016 https://en.wikipedia.org/wiki/Ethnic_groups_in_Botswana

Foote, L. (2014). Overview of premarital counselling. Retrieved from http://www.goodtherapy.org/pre-marital-counseling.html 
Grant, R., \& Asimeng-Boahene, L. (2006). Culturally responsive pedagogy in citizenship education: using African proverbs as tools for teaching in urban schools in the United States". Multicultural Perspectives, 8(4), 17-24. https://doi.org/10.1207/s15327892mcp0804_4

Indongo, N., \& Pazvakawambwa, L. (2015). Perceptions of Women on Marriage in Namibia. Psychology, 6, 1413-1420. https://doi.org/10.4236/psych.2015.611137

Jobeta, T., \& Nwauche, E. S. (2015). Double marriages in Botswana: Possibilities implications and comparative perspectives. Int J Law Policy Family, 29(1), 121-131. https://doi.org/10.1093/lawfam/ebu020

Masenya, M. (1998). Ngwetsi (bride):The Naomi-Ruth story from an African woman's perspective. Journal of Feminist Studies in Religion, 14(2), 81-90.

Masenya, M. (2005). HIV/AIDS and African Biblical hermeneutics focus on South African women. Chikana, 3(5), 127-156.

Moeti, B., Koloi-Keaikitse, S., \& Mokgolodi, H. L.(2017). Married women's lived experiences on the value of traditional premarital counselling 'go laya' on marital stability in Botswana. The Family Journal: Counselling Therapy for couples and Families, 1-10.

Mogapi, K. (1994). Ngwao ya setswana. Gaborone: Penrose Book Publishers.

Moloko-Phiri,S. S., Malaudzi, F. M., \& Heyns, T. (2016). Women abuse under the guise of culture and language use: Women narrate their stories. The Oriental Anthropologist, 16(2), 245-259.

Musick, K., \& Bumpass, L. (2006). Cohabitation, marriage, and trajectories in well-being and relationships. California Center for Population Research, Retrieved from, http://escholarship.org/uc/item/34f1h2nt

Nicolson, R. (2008). Persons in community African ethics in a global culture, University of Kwazulu-Natal Press: South Africa.

Nwoye, A. (2000). Building on indigenous: theory and method of marriage therapy in contemporary Eastern and western Africa. Journal of Family Therapy, 22, 347-359. https://doi.org/10.1111/1467-6427.00157

Nwoye, A. (2006). Theory and method of marriage therapy in contemporary Africa. Contemporary Family Therapy, 28, 437-457. https://doi.org/10.1007/s10591-006-9021-z

Population and Housing Census. (2011) analytical report, retrieved 15 August 2016. www.cso.gov.bw/images/analytical_report.pdf

Rice, K. (2014). Ukuthwala in rural South Africa: Abduction marriage as a site of negotiation about gender, rights and Generational authority among the Xhosa. Journal of Southern African Studies, 40(2), 381-399. https://doi.org/10.1080/03057070.2014.896720

Riessman, C. K. (1990). Divorce talk: Women and men make sense of personal relationships, Rutgers University Press, USA.

Solway, J. (2017). "Slow marriage," "fast bogadi": Change and continuity in marriage in Botswana. Journal Anthropology Southern Africa, 40(v1), 309-322.

Stockton, R., Nitza, A., \& Bhusumane, D. (2010). The development of professional counselling in Botswana. Journal of Counselling and Development, 88, 9-12. https://doi.org/10.1002/j.1556-6678.2010.tb00142.x

Struber, J. (2008). Stigma prejudice, discrimination and health. Social Science and Medicine Journal, 67(3), 351-357. https://doi.org/10.1016/j.socscimed.2008.03.023

The holy Bible. (1984). The new King James Version, Thomas Nelson Publisher: Nashville.

Togarasai, L. (2013). Christianity and Hegemonic Masculinities: Transforming Botswana Hegemonic using the Jesus of Luke, Scriptura 112, 1-12. https://doi.org/10.7833/112-0-68

\section{Copyrights}

Copyright for this article is retained by the author(s), with first publication rights granted to the journal.

This is an open-access article distributed under the terms and conditions of the Creative Commons Attribution license which permits unrestricted use, distribution, and reproduction in any medium, provided the original work is properly cited. 